\title{
Photovoltaics: new policy challenges for Europe
}

\author{
Luís de Sousa* \\ Resource Centre for Environmental Technologies (CRTE), Public Research Centre (CRP) Henri Tudor, Esch-sur-Alzette, Luxembourg
}

\section{Edited by:}

Simone Bastianoni, University of Siena, Italy

Reviewed by:

Bin Chen, Beijing Normal University, China

Payman Dehghanian, Texas A\&M University, USA

\section{${ }^{*}$ Correspondence:}

Luís de Sousa, Resource Centre for Environmental Technologies (CRTE), Public Research Centre (CRP) Henri Tudor, 6A, Av.des Hauts-Fourneaux, Esch-sur-Alzette L-4362, Luxembourg e-mail: luis.a.de.sousa@gmail.com
After the turn of the century governments across Europe set in place a series of programmes to expand investment on grid-connected solar power technology, especially photovoltaics (PV). But in face of rapidly declining costs most of these programmes have been tapered in recent months. Using a simple cost model this article shows that PV technologies can indeed supply electricity to the grid for less than $0.10 € / \mathrm{kWh}$ in large swaths of the continent, apparently justifying this policy change. However, the roll back of fixed rates to PV suppliers will likely result in a market structure close to perfect competition, where profits are not expectable and the price should fall towards marginal generation cost: $0 € / \mathrm{kWh}$. Due to the scalable nature of $\mathrm{PV}$, many consumers in Europe are now able to produce their own electricity at a cost considerably lower than the rates demanded by grid utilities. Investment on PV is thus set to continue in spite of recent policy changes, but henceforth on off-the-grid systems, conceived for self consumption. Long term this trend presents serious challenges to utilities and traditional electricity suppliers, putting at stake the existing electricity market framework.

Keywords: photovoltaics, electricity cost, electricity supply, electrical grid, electricity storage

\section{INTRODUCTION}

The Renewable Energy Sources Act (2000) passed in Germany is regarded today as the turning point for solar power technologies in Europe. It introduced mechanisms on which many other member states inspired their own legislation: the mandatory purchase of renewable electricity by utilities at a fixed price for a fixed period (Couture and Gagnon, 2010). Also known as feed-in tariffs (FIT), these mechanisms triggered watershed development of solar technologies, with PV emerging as a clear winner (del Río González, 2008).

Economies of scale cut manufacturing costs with the outsourcing of production overseas; in parallel, the technology itself has been subject to steady gains in efficiency (Green et al., 2012; McConnell and Fthenakis, 2012). To these add the increased experience by system installers, that too has cut costs considerably. The German Solar Industry Association keeps record of average PV system installation prices ${ }^{1}$; from over $5000 € / \mathrm{kWp}$ at the beginning of 2006, the average price has declined threefold to $1650 € / \mathrm{kWp}$ today. It is possible that innovation dynamics alike those seen for other technologies are in place for PV, such as Moore's Law for micro-processors (Schaller, 1997).

These cost developments may deem incentives to solar technologies a success, one of the reasons why governments are now largely rolling back FIT programmes. In certain cases the motivation has been the impact on spot electricity prices, that are now too low to support traditional electricity suppliers ${ }^{2}$. The growth of PV can likely resume without FIT, especially since it is a highly scalable technology, with a cost structure almost independent of system

${ }^{1}$ http://www.solarwirtschaft.de/preisindex

${ }^{2}$ Recently reported in the press, such as: http://www.bloomberg.com/news/ 2013-01-16/european-power-for-february-rises- on-freezing-weather-forecasts. html size, in essence accessible to everyone. However, such growth may not be as straightforward as it may seem.

This article starts by presenting a simple model to assess the lifetime cost of the electricity generated by $\mathrm{PV}$, in terms directly comparable to grid rates (Section 2). This model is then applied in Section 3 to the optimal generation figures assessed by the Joint Research Centre to produce PV electricity cost maps for Europe. Section 4 reflects on the challenges imposed by the complete roll back of FIT, considering the unique characteristics of the electricity market. Section 5 closes laying out a set of open research questions born out of this particular market setting.

\section{A SIMPLE PV ELECTRICITY COST MODEL}

Both nuclear and fossil based electricity suppliers have their costs tied to the regular supply of a fuel. Fossil fuels represent themselves the largest cost in operating a thermal power plant, making it difficult to project costs into the future. In contrast, PV (and most other renewable electricity technologies) demand few operational expenses, allowing for a relative accurate estimate of lifetime costs for the electricity produced.

In its simplest form, the cost of the electricity generated by a solar system $(C)$ is the ratio between total expenditures $(I)$ and the total amount of energy produced during its lifetime $(E)$ :

$$
C=I / E
$$

Expenditures can be decomposed in two main components: upfront investments and maintenance. Investment can itself be decomposed into modules $\left(I_{p}\right)$, inverter $\left(I_{i}\right)$, and installation $\left(I_{l}\right)$. Maintenance can also be decomposed into the replacement of the inverter - which usually does not last as long as PV modules - and yearly costs on other tasks such as cleaning or replacing cables $(M)$. 
The expenditures side of the equation can thus be expanded to:

$$
I=I_{p}+I_{l}+\left(L_{p} / L_{i}\right) * I_{i}+L_{p} * M
$$

Where $L_{p}$ is the system lifetime and $L_{i}$ the inverter lifetime, both expressed in years.

To compute the total amount of energy produced by the system in the first place it must be known the expected energy output per capacity unit at the site of installation. Taking into account daily and seasonal variations in the inclination of direct radiation, cloud cover, diffuse radiance, and atmospheric turbidity (Hofierka and Súri, 2002) it is possible to compute the energy generated per unit of installed capacity per year $\left(E_{c}\right)$, expressed in Wh/Wp/year. A second component required to calculate the total amount of energy generated is the decline of cell efficiency with time $(d)$, induced by material degradation. The energy component of the cost equation is thus expanded:

$$
E=\sum_{t=0}^{L_{p}-1}\left[E_{c} *(1-t * d)\right]
$$

Recent price declines have rendered a household size PV system an accessible investment: a $3 \mathrm{kWp}$ system can be installed for $<5000 €$, cheaper than any automobile. Still, it is reasonable to assume that some investors may recur to financing (especially for larger investments). Financing costs can be calculated using another time horizon $(F l)$ and an interest rate $\left(F_{r}\right)$, applied to a fraction of the upfront investment $\left(F_{f}\right)$. The expenditures equation is expanded to include this extra component:

$$
I=\left(I_{p}+I_{l}+I_{i}\right) *\left(1+F_{f} * F_{r} * F_{l}\right)+\left(L_{p} / L_{i}-1\right) * I_{i}+L_{p} * M
$$

A small open source web application implementing this model was developed ${ }^{3}$ and can be used on-line ${ }^{4}$.

\section{PV ELECTRICITY COST SCENARIOS}

The model presented above provides an electricity cost figure in $€ / \mathrm{kWh}$ for the full system lifetime. This way it not only allows a direct comparison with the cost of electricity provided by traditional energy suppliers, but also to the price paid by consumers to grid utilities. In this section two cost scenarios are developed, one with basic costs (hardware, installation, and maintenance), and a second including financing.

\subsection{SCENARIO I: BASIC COSTS}

PV installer companies usually provide an "all in" system price, but in order to estimate the cost of replacing the inverter hardware this bulk value must be unbundled into modules $\left(I_{p}\right)$, inverter $\left(I_{i}\right)$, and installation $\left(I_{l}\right)$ (paper work, labour, taxes, etc). The Photon magazine ${ }^{5}$ tracks prices in $€ / \mathrm{kWp}$ for both PV cells and inverters; the former stands presently at $0.6 € / \mathrm{kWp}$, with the latter at

\footnotetext{
${ }^{3}$ https://github.com/ldesousa/spcc

${ }^{4}$ http://attheedgeoftime.blogspot.com/2013/08/solar-power-cost-calculator-spcc. html

${ }^{5}$ http://photon-international.com/photon
}

$0.2 € / \mathrm{kWp}$. A good estimate for inverter lifetime $\left(L_{i}\right)$ is the warranty time provided by the maker, usually 10 years, even though recent assessments point to longer lifetimes (Heacox, 2010). For system efficiency decay a possible estimate is $0.5 \%$ /year, on the high side of research conducted on the matter (Chianese et al., 2003). For remaining maintenance expenses a figure of $0.02 € / \mathrm{Wp} /$ year is used, reflecting simple operations such as cleaning, and in line with other PV cost assessments (Zweibel, 2010). Table 1 summarises all these parameters and the values used to reach a first PV energy cost scenario.

With these parameters the model can be applied to the optimal irradiation figures provided by the European Photovoltaic Geographic Information System (PVGIS) (Suri et al., 2008). Figure 1 portraits results for a system lifetime of 20 years. The contribution of each parameter to total cost is shown in Figure 2, together with cost as a function of system lifetime for three reference sites. Figures as low as $0.10 € / \mathrm{kWh}$ are possible already at the Alpine region, with much of the continent below $0.14 € / \mathrm{kWh}$. For a 30year lifetime project costs get close to $0.06 € / \mathrm{kWh}$ in member states like Portugal, Spain, Italy (Sicily), or Cyprus; this is in line with rates recently demanded by investors ${ }^{6}$.

\subsection{SCENARIO II: INCLUDING FINANCING}

A second scenario can be devised with the addition of financing. This scenario builds on the previous base case with the addition of an 8 -year loan $\left(F_{l}\right)$ covering $80 \%$ of the upfront investment $(F f)$ at a $2 \% /$ year interest rate $\left(F_{r}\right)$. These parameters are resumed in Table 2.

Figure 3 presents again the model applied to PVGIS data; with the contribution of each parameter to end cost, and the updated costs as function of lifetime shown in Figure 4. The $0.10 € / \mathrm{kWh}$ threshold moves visibly south, but interesting values are still registered in Portugal, Spain, Italy (Sicily), the Adriatic coasts, and Cyprus; the Alpine region also remains in evidence.

\section{THE EXCEPTIONAL NATURE OF PHOTOVOLTAICS}

The model proposed above shows PV electricity costs clearly coming to level with traditional electricity suppliers. PV technologies with longer lifetimes can already be the cheapest source of electricity in some member states, when compared to the costs of building anew a traditional power plant (Brinckerhoff, 2010). Scrapping FIT programmes might seem well justified at this stage, with PV able to remain in the market by itself, providing a secure, indigenous electricity source with low environmental impact. There are

\footnotetext{
${ }^{6}$ As reported by the press: http://www.finanzas.com/noticias/empresas/20120919/ varios-inversores-interesados-instalar-1537691.html

Table 1 | Parameters used to compute basic PV electricity costs.

\begin{tabular}{llll}
\hline Upfront investment & Modules & $I_{p}$ & $0.6 € \mathrm{~Np}$ \\
& Inverter & $l_{i}$ & $0.2 € \mathrm{Wp}$ \\
Installation & $I_{i}$ & $0.85 € \mathrm{Wp}$ \\
Maintenance costs & & $L_{i}$ & 10 years \\
System efficiency decay & & $M$ & $0.02 € / \mathrm{Wp} /$ year \\
& & $d$ & $0.5 \% /$ year
\end{tabular}
}




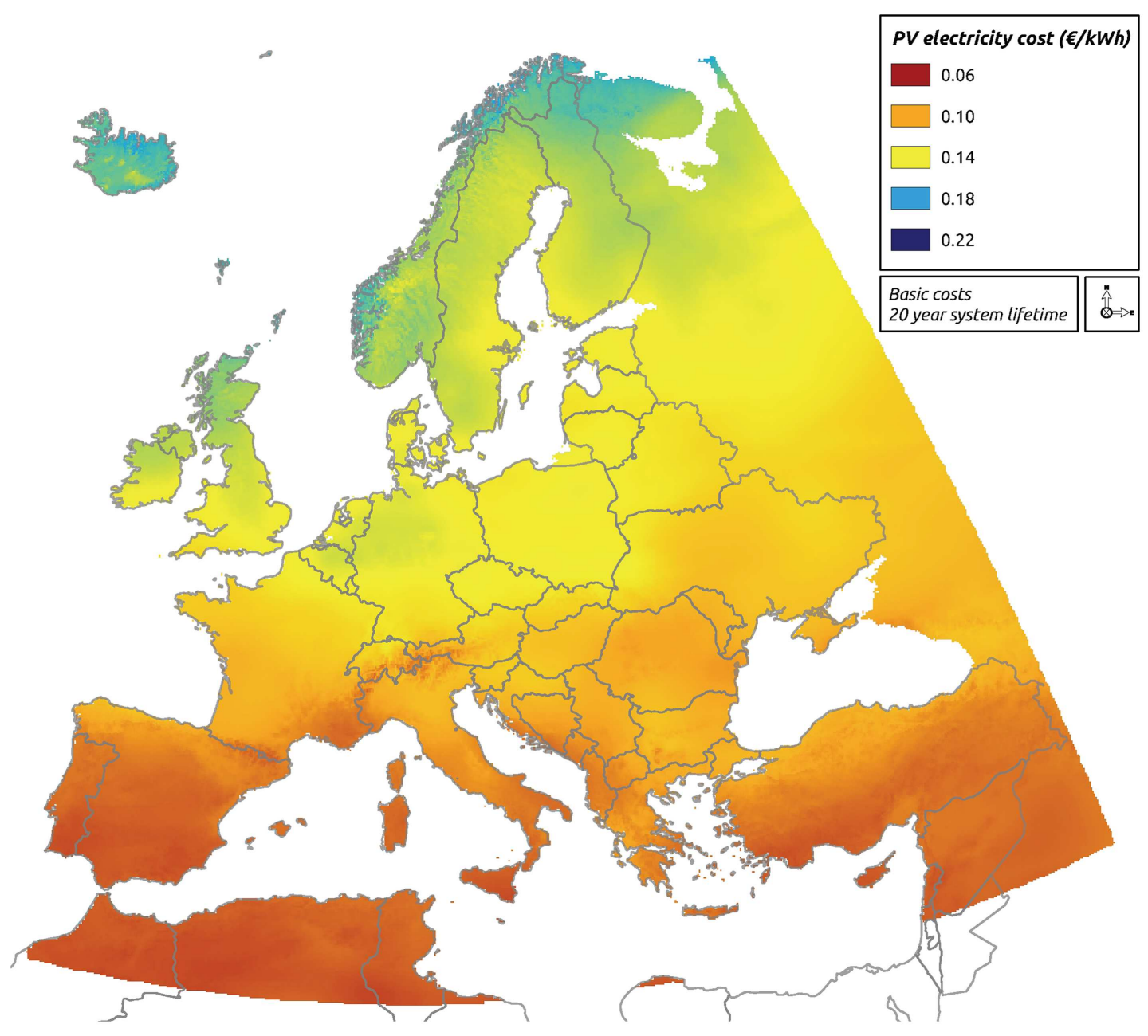

FIGURE 1 | Basic costs of PV electricity in Europe for a 20-year system lifetime

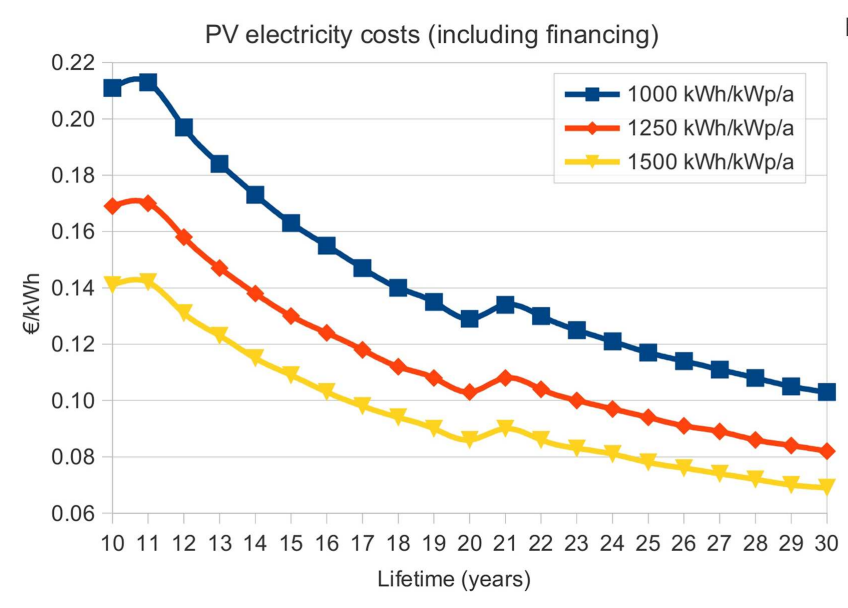

PV electricity cost components (20 years lifetime)

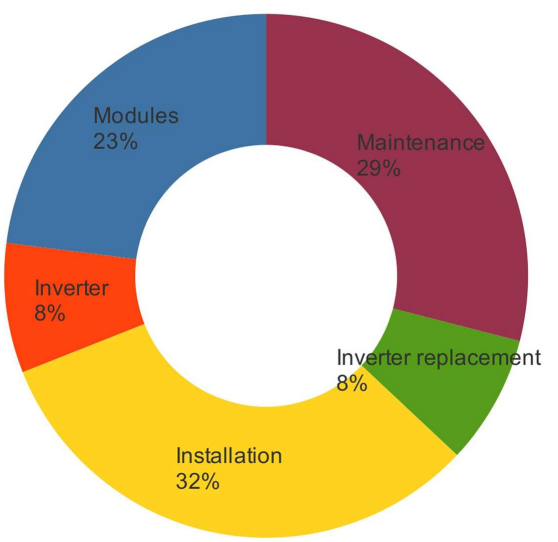

FIGURE 2 | Basic PV costs as function of lifetime and cost composition for three hypothetical sites. 
though particular characteristics to PV and the electricity market that beg for closer inspection.

Once injected into the grid an electron is equal to any other, and whenever a PV system is feeding the grid, all other systems in the region are also generating electricity at similar rates per kWp. Large or small, all PV systems produce exactly the same product at exactly the same time with no differentiation whatsoever. These three characteristics: (i) vast number of suppliers, (ii) a completely homogeneous product, and (iii) the absence of economies of scale, are the core of what is know in Economics as a perfect competition (or perfect concurrency) market. The outcomes of such structure must be fully understood.

Table 2 | Additional parameters used to compute basic PV electricity costs including financing.

\section{Financing time horizon} Investment fraction financed Interest rate

$\begin{array}{ll}F_{l} & 8 \text { years } \\ F_{f} & 80 \% \\ F_{r} & 2 \% / \text { year }\end{array}$

The understanding that prices tend to be lower in markets with a large number of suppliers roots back to Mercantilism studies of the XVII century (McNulty, 1967). By the midst of the XVIII century the concept of product differentiation was already present in Economics texts (Hume, 1955); Competition was also widely understood at that epoch (McNulty, 1967). The concept of perfect competition can possibly be attributed to Setuart (1767), who observed that a market where both suppliers and buyers compete among themselves will tend to a perfect balance, avoiding excessive or underrated prices relative to marginal cost. According to Monroe (1948) it was also about this time that French economist Turgot observed that rife competition among farmers lead them to pay all surpluses to land proprietors. Already in the XX century mathematical economists came to formalise the concept as a situation where from the point of view of an individual supplier the market price is unresponsive to quantities traded (Stigler, 1957). This market structure has been regularly revisited, with the discussion open on the exact set of requirements for perfect competition (Lăculeanu, 2007).

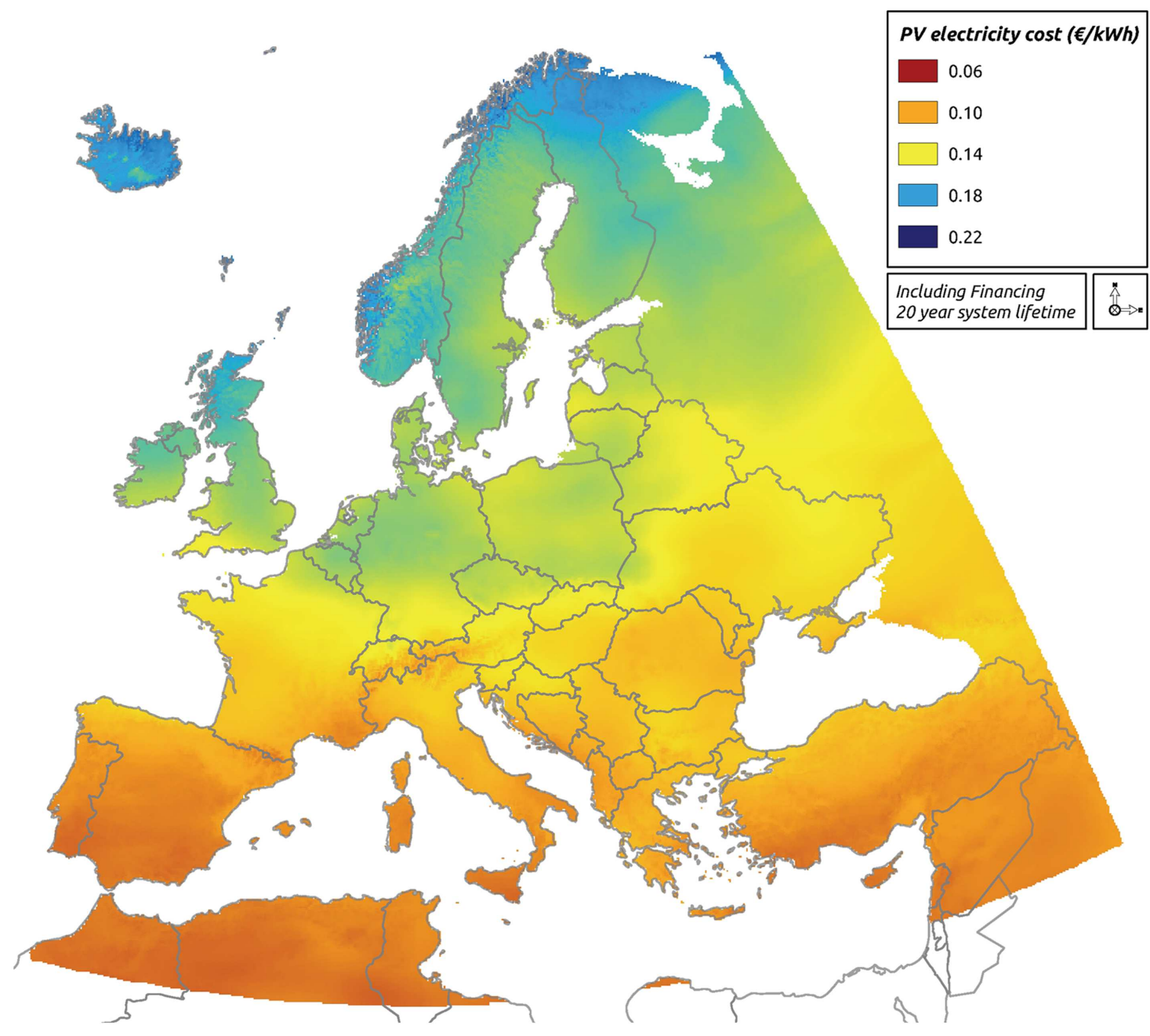

FIGURE 3 | PV electricity cost in Europe including financing for a 20-year system lifetime. 


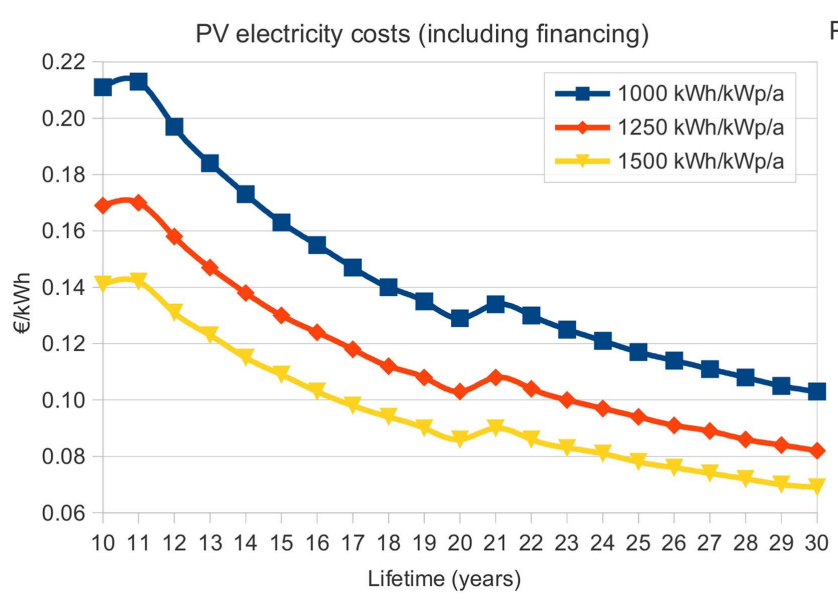

PV electricity cost components (20 years lifetime)

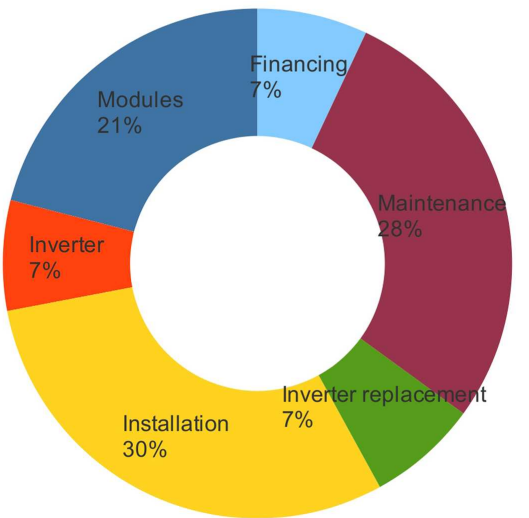

FIGURE 4 | PV costs including financing as function of lifetime and cost composition for three hypothetical sites

As the economists of the XVIII century understood, a Perfect Competition market has an important characteristic: long term price tends to match marginal costs and supply agents struggle to make a profit (Samuelson and Nordhaus, 1998) (this is one of the reasons for secular subsidies to agriculture). In the case of PV, a system already in place hardly runs costs to generate electricity; contrary to traditional electricity suppliers, it does not require fuel inputs and maintenance costs are very low. It follows that in a market dominated by this type of suppliers the price should approach 0 (zero)€/kWh. This explains why spot electricity prices collapse during sunny summer days, even entering negative territory ${ }^{7}$. It can be argued that negative prices occur by lack of price feedback to suppliers, but even with such information the approximation of spot prices to zero should be the expected outcome in a market dominated by $\mathrm{PV}$ (and similar renewable energy) suppliers.

A perfect competition market with a marginal cost of zero is something totally outside the standard study and practice of Economics, resulting not only in null surpluses but also in null revenues. No rational supplier should be expected to remain in such market. Therefore it seems safe to conclude that without FIT programmes, or similar mechanisms guaranteeing long term revenues, PV will henceforth grow off-the-grid, providing electricity exclusively for self consumption. In such setting PV becomes not an investment to provide monetary revenues but rather to tap low cost electricity. This paradigm requires an extra expense on storage hardware, that can only be justified if the difference between basic PV costs and grid electricity rates is wide enough. Using the price statistics collected by the EuroStat ${ }^{8}$ this difference can be computed from the results of Section 3 (Figure 5).

There are several groups of member states worth noting, in first place the sunniest: Portugal, Spain, Italy, and Cyprus. Beyond

${ }^{7}$ See for instance: http://cleantechnica.com/2012/04/15/renewables-drivingelectricity-prices-to-negative-some-afternoons-cutting-into-baseload-powerplants-market-share/\#RGQ5Avu6UC6xLLjb.99

${ }^{8} \mathrm{http} / / /$ appsso.eurostat.ec.europa.eu/nui/show.do?dataset=nrg_pc_204\&lang=en the sun these member states also share relatively high taxes on electricity and VAT. Another group is formed by Denmark and Germany, that although in the north, also employ heavy taxes on electricity. These six member states are those where off-thegrid PV is likely set for an earlier start. Right behind are Ireland, Belgium, and Austria, where PV for self consumption is already worthy of consideration. The south of France, the Netherlands, Sweden, Hungary, and Greece are at the door steps, further progresses in $\mathrm{PV}$ or storage technologies may turn these member states also into fertile ground for off-the-grid PV.

The economics of off-the-grid systems is highly dependent on daily, seasonal, and annual consumption profiles. The scaling of generation capacity, battery size, and battery lifetime, must all be adjusted to the gap between basic system costs and grid rates, minimising the usage of electricity supplied by the grid. For a household that is able to use the storage system to back up further scalable power sources (e.g., wind, geothermal), or combine storage with electrical mobility, the investment becomes more economical but also more complex to dimension. This is a topic well beyond the scope of this article, it is however important to note that in a case like Spain, where the gap between PV electricity costs and grid rates can reach $0.15 € / \mathrm{kWh}$, the investor may simply dispense any storage system, waste up to two thirds of the electricity generated, and still get it cheaper.

\section{OPEN QUESTIONS}

The electricity market in Europe seems bound to an unprecedented transition. From centralised, imported, and non-renewable supplies, a decentralised, indigenous, and renewable network is now an economical possibility. If on the surface this may seem a positive development, it is in fact bringing forth a series of new challenges that demand a new focus for energy policy research in Europe.

The smart grid concept (Amin and Wollenberg, 2005) has been touted in recent years as one of the key steps to cement the presence of renewable suppliers to the electricity market. This concept translates into a spot market where both suppliers and 


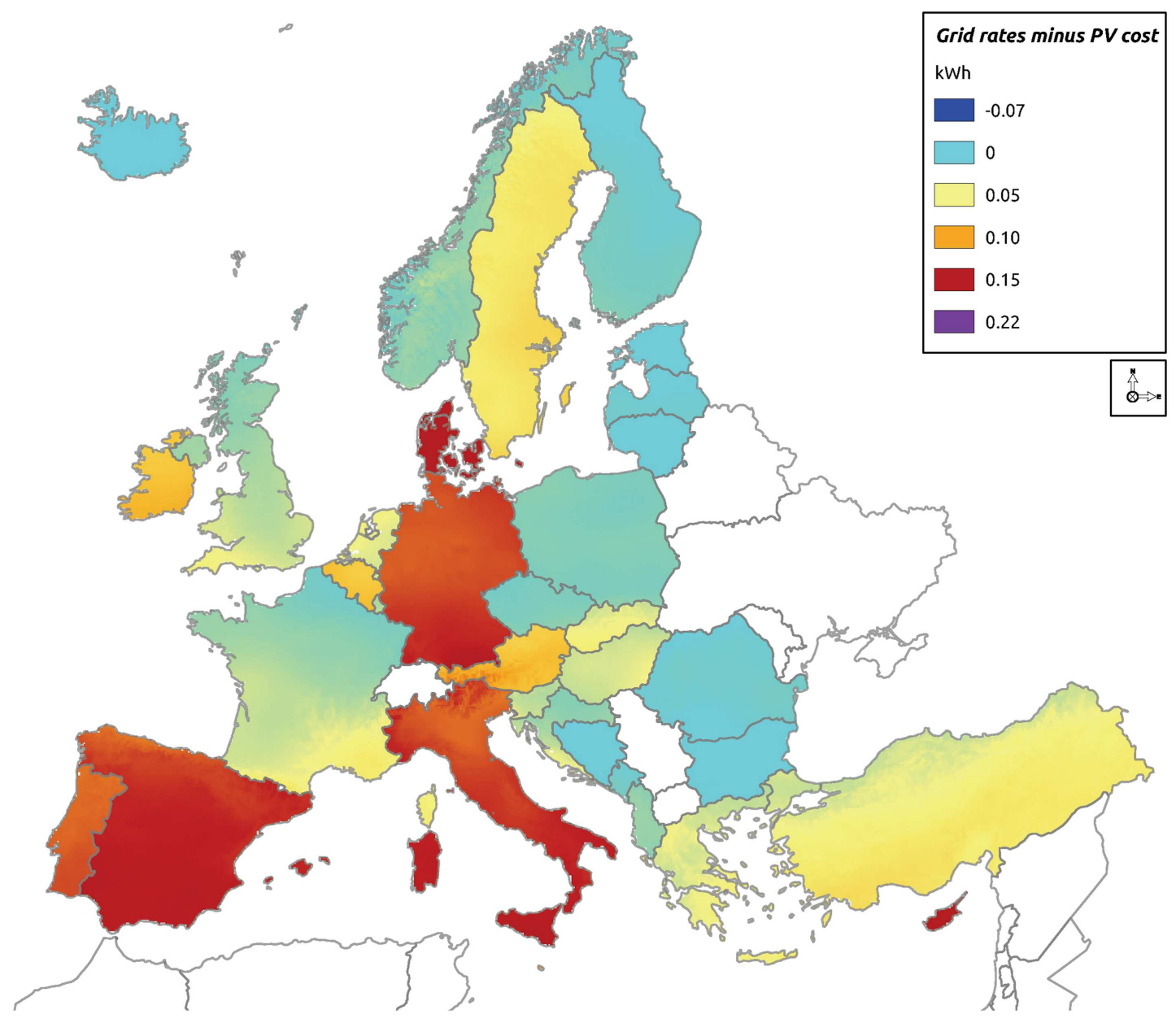

FIGURE 5 | Difference between grid electricity rates for households and basic PV costs

consumers act on real time prices, thus adjusting their immediate demand/supply on the grid. Considering the perfect competition structure described above, it seems doubtful such market can provide proper revenues (let alone profits) to PV suppliers without long term contracts. Before deploying the required infrastructure on a relevant scale, this market paradigm must be thoroughly assessed through adequate market simulation tools.

A second field of research arising from these results is the scaling of off-the-gird systems. As already referred, the combination of off-the-grid PV with complementary household scale technologies, such as wind or geothermal, must be performed on an ad hoc basis, adjusting the system to the specific needs of each consumer. Beyond households, opportunities may also exist to work at the community level, especially in northern Europe, where renewable energy cooperatives have proliferated in recent years. Seizing these opportunities requires expertise and tools that may not yet be fully mature.

Another important question is the fate of the existing centralised grid. Can it be fully dispensed or will it prevail as a back up for decentralised networks? The answer possibly lies on the policy adopted towards small scale renewable suppliers. If the option is for the full roll back of FIT the centralised grid will likely retain its actual form, but providing ever less electricity at ever higher rates. Is such a grid sustainable long term? Otherwise the grid may progressively morph into a decentralised network, possibly with decentralised back up infrastructure. What are the risks to such decentralisation? To what extent can such network be resilient? And at what cost?

Finally a note on storage: the gaps observed between grid rates and basic PV costs are in themselves a great incentive to electricity storage research. Specific policies may not be required on this field, but authorities must be aware that further developments in this area can have profound consequences.

In July of 2013 the European Union agreed with the People's Republic of China a floor on the price of imported solar cells, supposedly as an anti-dumping measure. In practice this translates into a guaranteed profit for Chinese manufacturers at the expense of European investors. The same month the Spanish government proposed an unheard of tax on sunshine, in order to offset the gap between grid rates and PV costs; such policy mimics the feudal system that ruled access to arable land in Mediaeval times. It is precisely to avoid such policies that research on PV (and perhaps 
other renewables) must step into a new phase, fully embracing the low cost reality. If for nothing else, for pure social reasons.

\section{REFERENCES}

Amin, S., and Wollenberg, B. (2005). Toward a smart grid: power delivery for the 21st century. Power Energy Mag. IEEE 3, 34-41. doi:10.1109/MPAE.2005.1507024

Brinckerhoff, P. (2010). Powering the Nation. Technical report. New York: Parsons Brinckerhoff.

Chianese, D., Realini, A., Cereghetti, N., Rezzonico, S., Bura, E., and Friesen, G. (2003). Analysis of Weather c-si pv Modules. Technical report, LEEE-TISO, University of Applied Sciences of Southern Switzerland, Manno.

Couture, T., and Gagnon, Y. (2010). An analysis of feed-in tariff remuneration models: implications for renewable energy investment. Energy Policy 38, 955-965. doi:10.1016/j.enpol.2009.10.047

del Río González, P. (2008). Ten years of renewable electricity policies in Spain: an analysis of successive feed-in tariff reforms. Energy Policy 36, 2917-2929. doi:10.1016/j.enpol.2008.03.025

Green, M. A., Emery, K., Hishikawa, Y., Warta, W., and Dunlop, E. D. (2012). Solar cell efficiency tables (version 39). Prog. Photovolt. Res. Appl. 20, 12-20. doi:10.1002/pip. 2163

Heacox, E. (2010). Inverter cost analysis. Solar Industry 28-31.

Hofierka, J., and Súri, M. (2002). "The solar radiation model for open source gis: implementation and applications," in Proceedings of the Open Source GIS - GRASS Users Conference, Trento.

Hume, D. (1955). Writings on Economics. Madison: University of Wisconsin Press.

Lăculeanu, E. P. (2007). The level of concentration of the enterprises from the industry, construction and services. Ann. Univ. Petrosani Econ. 7, 253-258.

McConnell, R., and Fthenakis, V. (2012). "Concentrated Photovoltaics," in Third Generation Photovoltaics, ed. V. Fthenakis (InTech). doi:10.5772/39245

McNulty, P. J. (1967). A Note on the History of Perfect Competition. J. Polit. Econ. 75, 395-399. doi:10.1086/259295

Monroe, A. E. (1948). Early Economic Thought. Harvard University Press.

Renewable Energy Sources Act. (2000). Act on Granting Priority to Renewable Energy Sources. The Federal Ministry for the Environment, Nature Conservation and Nuclear Safety, Germany.
Samuelson, P. A., and Nordhaus, W. D. (1998). "Analysis of perfectly Competitive Markets," in Economics (New York: McGrawHill), 137-145.

Schaller, R. (1997). Moore's law: past, present and future. IEEE Spectrum 34, 52-59. doi:10.1016/j.rbmo.2012.08.006

Setuart, J. (1767). An Inquiry into the Principles of Political Oeconomy. London: A. Millar \& T. Cadell. Available from: http://marxists.org/reference/subject/ economics/steuart/index.htm

Stigler, G. J. (1957). Perfect Competition, Historically Contemplated. J. Polit. Econ. 65, 1-17. doi: $10.1086 / 257878$

Suri, M., Huld, T., Dunlop, E. D., and Cebecauer, T. (2008). Geographic aspects of photovoltaics in Europe: contribution of the PVGIS website. IEEE J. Sel. Top. Appl. Earth Observ. Remote Sensing 1, 34-41. doi:10.1109/JSTARS.2008. 2001431

Zweibel, K. (2010). Should solar photovoltaics be deployed sooner because of long operating life at low, predictable cost? Energy Policy 38, 7519-7530. doi:10.1016/j.enpol.2010.07.040

Conflict of Interest Statement: The author declares that the research was conducted in the absence of any commercial or financial relationships that could be construed as a potential conflict of interest.

Received: 26 August 2013; accepted: 22 November 2013; published online: 09 December 2013.

Citation: de Sousa L (2013) Photovoltaics: new policy challenges for Europe. Front. Energy Res. 1:7. doi: 10.3389/fenrg.2013.00007

This article was submitted to Energy Systems and Policy, a section of the journal Frontiers in Energy Research.

Copyright (c) 2013 de Sousa. This is an open-access article distributed under the terms of the Creative Commons Attribution License (CC BY). The use, distribution or reproduction in other forums is permitted, provided the original author(s) or licensor are credited and that the original publication in this journal is cited, in accordance with accepted academic practice. No use, distribution or reproduction is permitted which does not comply with these terms. 